\title{
Teacher Development in Slovenia for Teaching Foreign Languages at the Primary Level
}

Mihaela Brumen ${ }^{1}$ and Mateja Dagarin FojKar ${ }^{\star 2}$

$\approx$ The introduction of foreign languages into the first three-year cycle of primary school has spurred the need for qualified teachers, and is one of the main discussion points among experts in foreign language teaching. Most of the contemporary studies report that there is a global gap between the supply of qualified teachers of foreign languages to young learners and the demand for them as programmes expand. These studies emphasize the paramount importance in assuring the quality of early foreign language instruction. Therefore, the authors of this paper first present some of the models of initial and in-service training of teachers of foreign languages to young learners across the world and then focus on a more in-depth presentation and analysis of the training of teachers of foreign languages at the primary level in Slovenia. All the existing national programmes for teacher development are compared and discussed. Finally, some guidelines and recommendations are given regarding training teachers to teach foreign languages to young learners.

Keywords: initial teacher training, in-service teacher training, primary level, teaching foreign languages 


\section{Izobraževanje učiteljev za poučevanje tujih jezikov v osnovni šoli v Sloveniji}

Mihaela Brumen in Mateja Dagarin Fojkar ${ }^{*}$

$\propto$ Pri vpeljavi učenja tujih jezikov v prvo triletje osnovnošolskega izobraževanja se je pokazala potreba po usposobljenih učiteljih za to poučevanje, hkrati pa je to postala ena izmed osrednjih diskusij med strokovnjaki na področju poučevanja tujih jezikov. Večina trenutnih raziskav kaže, da je velika diskrepanca med ponudbo usposobljenih učiteljev za poučevanje tujih jezikov mlajših učencev in potrebami, ki se ob širitvi programov še povečujejo. V raziskavah je poudarjeno, kako pomembno je zagotoviti kakovost pri zgodnjem poučevanju tujih jezikov. V prispevku so najprej predstavljeni nekateri tuji modeli začetnega in nadaljnjega izobraževanja učiteljev za poučevanje tujih jezikov mlajših učencev. Nato je podrobneje predstavljen in analiziran sistem izobraževanja učiteljev za poučevanje tujih jezikov na razredni stopnji (prvi dve triletji osnovne šole) v Sloveniji. Primerjani in analizirani so vsi obstoječi programi za izobraževanje in usposabljanje učiteljev. $\mathrm{Na}$ koncu je predstavljenih nekaj smernic in predlogov za izobraževanje učiteljev za poučevanje tujih jezikov mlajših učencev.

Ključne besede: začetno izobraževanje učiteljev, nadaljnje izobraževanje učiteljev, razredna stopnja (prvi dve triletji), poučevanje tujih jezikov 


\section{Introduction}

Different contemporary studies on teaching foreign languages to young learners (Chodiah, 2008; Emery, 2012; Enever, Moon, \& Raman, 2009; Enever, 2011; Garton, Copland, \& Burns, 2011; Graddol, 2006; Graddol, 2008; Wang, 2002, 2007, 2009) emphasize some of the problems occurring as a result of inadequate preparation for teaching at this level: for example teachers' inabilities to deal with problems that occur in the teaching context because of lack of training, employers' acceptance of low-level qualifications to teach young learners, teachers' inadequate foreign language proficiency and the fact that some teachers are required to teach English although this is not their subject specialism. If teachers are not well-qualified to sustain effective provision of primary foreign language instruction, it will certainly affect primary foreign language practice.

The aim of this paper is to present a wide range of foreign language environments, programmes and practices in teacher training or development designed to support foreign language instruction for primary-aged learners. These studies describe the models of teacher education for carrying out foreign language instruction with teachers who are not well prepared, approaches and strategies for improving teachers' ability to speak and teach in foreign languages, and their teacher development programmes. Next, the article describes and analyses in detail teachers' qualifications, training and development in Slovenia, and attempts to highlight how the country's educational system has developed teacher development for primary language instruction and is competing with demands to include foreign languages in the primary school setting.

\section{Current trends in teacher training for teaching foreign languages at primary level}

Recently, a number of excellent publications on teacher training and development have provided valuable insight into the specifics of teachers' qualifications and training (e.g. language proficiency improvement, assessment, classroom observations). Even though these publications raise awareness of the challenging nature of teacher development, concrete teacher qualifications and models or programmes of pre-service and in-service teacher training, their curriculum, competences, attitudes, values that are being developed, the descriptions of approaches/activities that are being taken, or teaching practice in different countries with regard to teaching foreign languages to young learners are, nevertheless, outside their scope. Recently, there have been promising 
attempts to provide some advice on how to improve initial teacher training or teacher development for teaching young foreign language learners.

The global study conducted by Emery (2012) is described in a more detailed way below, as it is the most up-to-date and thorough study of primary English teachers' qualifications, training, teaching experience and career development. The data were collected via the use of an electronic survey, which gathered almost 2,500 responses and in-depth face-to-face interviews with classroom teachers and head teachers in nine countries around the world. The subjects were rural and urban teachers who worked in state and private institutions. The findings indicate some global trends in areas including the widespread nature of English Language Teaching (ELT) and the drive to introduce English to ever younger learners. On the positive side, the findings indicate that class sizes are small for the majority of teachers (fewer than 35 children). However, one cause for concern is the low number of teachers with a degree, and the number of teachers who have undergone specific training to teach the age that they currently teach, or to teach English. These findings are balanced by the fact that 85 per cent of teachers report they have undertaken some sort of professional development training since starting to teach. Apparently, teacher training of language teachers of younger learners is gaining a more significant value worldwide; this trend can also be observed in Slovenia with new programmes for training teachers being developed (see below). In her findings, Emery (ibid.) offers several recommendations on initial teacher training to young foreign language learners.

One observation was that many teachers have not been specifically trained to teach English, or to teach the level that they currently teach. This will impact on children's learning and may also lead to teachers feeling stressed in their jobs.

Another specific finding that arose from the study was that younger or inexperienced teachers tended to teach the early grades, and more experienced or older teachers taught the upper grades. In some contexts, promotion for a teacher means moving up the school to teach the higher levels. Fortunately, this is not the case in Slovenia.

It is strongly recommended that education providers recognize that teaching younger learners is a worthy and highly demanding profession and not just a starting point for newly qualified and inexperienced teachers. Such awareness is also needed in Slovenia, as private language institutions often hire students or teachers with no language or pedagogic qualifications to teach younger children.

Some further recommendations by Emery (ibid.) are:

- Teachers of early years need specific training to teach this age group. 
- $\quad$ Teacher training needs to focus on the level to be taught by a teacher when they qualify, and training providers are encouraged not to continue with the current system of providing a generic teaching qualification, which does not focus on a particular age range or level of learner.

- Teachers of the English language need to be specifically trained to teach this subject.

- $\quad$ Students should only be selected for training as an English teacher if they have a good knowledge of the language, or if their training provides adequate instruction for them to acquire this knowledge (ibid.).

In her conclusion, Emery (ibid.) also suggested some recommendations for the professional development of teachers to young foreign language learners. She noted that teachers like professional development and see it as an essential part of their job. However, many teachers are still not receiving any inservice training. In some cases, head teachers have said that they find it difficult to release teachers for these courses as there is nobody to handle their classes while they are attending the courses. More in-service courses and workshops need to be made available for teachers, and these need not cost a great deal of money. Some ways of doing this could be:

- In-service workshops have to be taken into consideration when allocating staff timetables.

- Workshops could be organized at weekends so that teachers do not have to miss classes to attend them. Introducing more non-teaching days into the curriculum could be another solution to this problem.

- Attending professional development sessions could lead to promotion.

- $\quad$ Experienced teachers could be encouraged to present workshops at their school.

- $\quad$ Good teachers could be identified and asked to teach model lessons to a group of students, so that other teachers might watch and learn from them.

- $\quad$ Teachers need to be encouraged to carry out action research projects in collaboration with others. Findings and recommendations would be beneficial to the school or wider education community as a whole (ibid.).

Some of these recommendations have already been implemented into Slovenian in-service teacher training; for example, workshops are often executed in the afternoons and attendance leads to promotion. Universities, the $\mathrm{Na}$ tional Education Institute and some publishing houses invite foreign language teachers to present their model lessons, materials and good teaching practice. 
Nevertheless, the previous recommendations given by Emery (ibid.) should also be better supported in Slovenia, and teachers should be encouraged to share good practices and their experience and especially to carry out action research projects, which would provide much needed data in the field of teaching foreign languages to children.

Other international experience also shows that investment in in-service teacher training/development can have a positive impact on the quality of schooling (Pennycuick, 1993). Hayes (2006, p. 141) claimed there is not, however, a simple one-to-one correspondence between any in-service teacher training course and improved practice in the classroom. As Hayes (ibid.) reported, there are sufficient examples of in-service courses having limited or no impact on the teachers involved, particularly in the long term (see, e.g. Ibrahim, 1991; Lamb, 1996; Moon \& Boullớn, 1997; Jones \& Coffey, 2006, p. 174), to give considerable pause for thought. Teachers may adopt external features of a new curriculum, while in practice they continue to use the tried and trusted methods with which they have long been familiar.

However, Lundberg (2007) suggested a good solution, based on the example of a three-year action research project within the in-service education for language teachers of young learners in Sweden. She drew on her experience with 160 teachers participating in a programme challenging common routines, as teachers applied a research-based, age-appropriate methodology based on their learners' needs. The most significant finding of the project was the realisation of how difficult it is to bring about any change in methodology within a school culture that has strongly embedded teaching traditions. The project has shown that action research can be a useful tool for empowering language teachers and improving teaching and learning in young learners' classroom. Perhaps action research, with its cycles with no finishing point, has a better chance of dealing with resistance in the field of education and in-service training than other models. Teachers reported that the action research model felt like a powerful form of professional development, because it grew out of their own specific contexts and they were in control of the process by their planning, action and reflection.

In Slovenia, some efforts have been made to implement foreign language teaching and learning in the kindergarten curriculum in the form of the Network Innovative Project enriched with the strategies of action research (see also Brumen, 2011, pp. 720-723). Under the supervision of the Slovenian National Education Institute and the Faculty of Education of the University of Maribor, 12 kindergartens in the north-eastern part of Slovenia applied to participate in the network innovative project from 2008/o9 to 2010/11. The Network 
Innovative Project integrated foreign language learning in the content of other pre-school curriculum areas (e.g. movement, art, nature, society, mathematics).

The research shows that the children were highly motivated by their learning of a foreign language, which was evident in their intrinsic motivation. The children expressed the need for playful activities. They liked to learn the target language, because they were actively involved (e.g. talking, singing, playing, running, etc.), felt a sense of accomplishment and satisfaction after task completion, and expressed their foreign language knowledge.

However, some children disliked learning the foreign language and mentioned some inconvenient factors that bothered them. The children and the pre-school teachers in their reports perceived the need for a learning climate that offers a pleasant, safe, and supportive classroom atmosphere.

Pre-school teachers have learnt from this action research project how important it is to carefully plan an effective lesson, involving playful contents from the pre-school curriculum areas and to master good target language use so that children can learn in a rich target language environment.

Another example of the use of action research tools in Slovenian inservice teacher training is a two-year pilot project Foreign Language Communication/Implementing Foreign Languages and Language and Intercultural Awareness in the First Cycle of the Slovene Primary School, conducted between 2008 and 2010. The professional group consisted of 14 experts from the fields of (foreign) language learning, psychology, and pedagogy from different Slovene universities and the National Education Institute. The project group of teachers was represented by 62 teachers from 45 primary schools (Lipavic Oštir, 2010; Pevec Semec \& Pižorn, 2010). One of the project's main aims was also developing teachers' self-reflection, which was achieved through seminars, joint expert or regional meetings in which the participants observed and discussed lessons, portfolio writing, in which teachers presented their work and analysed it (ibid.). All these activities led to quality foreign language education at the primary level.

Noffke and Somekh (2009) claimed that action research projects in collaboration with educational institutions support this idea because it involves "learning by doing" where teachers attempt to resolve a real teaching problem, and through their systematic self-evaluation and self-reflection attempt to improve their teaching practice and find better, up-graded ways to their individual education. 


\section{Teachers' qualifications and training in different countries}

The necessity of adequate training for teachers has been emphasized in several reports (e.g.: Dendrinos, 2010; Edelenbos, Johnstone, \& Kubanek, 2006; Emery, 2012; Enever, 2011; Garton, Copland, \& Burns, 2011; Rixon, 1999); however, different countries may view the training requirements of teachers differently. Emery (2012) also added that in some countries a basic educational qualification is provided by the government, which is deemed sufficient for all teachers regardless of the age they will be teaching or the subject area. In other countries, teachers are given a more specialized training aimed at equipping them with the specific requirements of their future career.

The overview of literature shows that few publications on teacher training and development provide concrete, detailed teachers' qualifications, models or programmes, competences, or activities of pre-service and in-service teacher training in different countries in order to make some thorough synthesis or an "ideal" model based on experience from abroad. However, in this chapter an attempt is made to provide an insight into some other studies made in different countries that report on programmes that train teachers to meet the needs of young language learners. The presented countries were chosen for various reasons, but mainly due to their high standard of education, proximity or long tradition of early foreign language education. These studies address their teacher training programmes and give an overview of their attempts to implement teacher education at national and classroom levels.

\section{Finland}

Hildén and Kantelinen (2012) reported that both, specialist teachers and primary education teachers ${ }^{3}$ can teach foreign languages at the primary level; according to the Basic Education Decree, children in Grades 1-6 are taught primarily by primary education teachers and in Grades 7-9 by subject teachers. Primary education teachers choose to specialize in teaching foreign languages as an optional module (both, at pre-service and in-service level). The pre-service module for primary education teachers lasts 35 study weeks (at least 6o ECTS). The Finnish National Core Curriculum for Basic Education from 2004 leaves a great deal of pedagogical freedom to language teachers; they are

3 Explanatory note: in the article a specialist teacher is a teacher who specializes in teaching foreign language(s) but does not usually teach other subjects, whereas a primary education teacher is someone who teaches all subjects at lower primary levels. 
even required to write the local school-related curricula. In recent years foreign language learning has shifted from studying the structure of language towards studying the use of languages for real life purposes; therefore, an ever-growing number of teachers and their pupils are making exchange visits to other European countries and using the European Language Portfolio (ELP) in their classes. This shift can also be observed in the Slovene classrooms. Some of the propositions that the authors (ibid.) make include better language diversity (concentration on English is too heavy) and an early start of the languages that pupils are not exposed to in their daily lives. Furthermore, they suggest that language learning could be integrated into other subject content and supported by cooperation between teachers in different subjects, which was also one of the aims of the Slovene project Foreign Language Communication/Implementing Foreign Languages, and Language and Intercultural Awareness in the First Triad of the Slovene Primary School (Pevec Semec \& Pižorn, 2010). Hildén and Kantelinen (2012) conclude that research-based networks should be established between researchers, teacher educators, teachers and teacher students at the national and international level.

\section{Italy}

The turning point in the Italian primary foreign language education policy came in 2003-2004 when the government passed the legislation introducing English as a compulsory language from the first year of primary school. Calabrese and Dawes (2008) reported that due to lack of teaching staff, the government financed a nation-wide programme of in-service training with the immediate aim of training at least half of all primary teachers to teach a foreign language. A survey in 2005 revealed that only $30 \%$ of primary school teachers possessed the necessary competences and estimated that 69,000 teachers needed to be trained (ibid.). This led to several nationwide teacher training programmes. The authors described in detail a training scheme that could be used for developing a national framework for a systematic primary teacher language education programme. The main aim of the scheme was to develop the trainees' linguistic and communicative competences in English at A2 or B1 level and to provide them with the basic knowledge of foreign language teaching methodology. The prevailing principle during the process of selecting topics to be taught was that the trainees themselves, just as their young learners, should experience the language that encourages them to process language for meaning (ibid.). Consequently, the topics proposed by the authors were related to the primary school context and were closely connected to the seven syllabus areas 
(grammar, lexis, phonology, functions, language skills, content- and languageintegrated learning (CLIL) indications and classroom language) included in the in-service programme. The authors also stressed the importance of trainees' personal commitment and motivation to attend courses after a demanding day at school and the need to build their self-confidence in language. An idea that could also be partly implemented in the Slovenian training programmes is a special language syllabus in which linguistic content is embedded with methodological content through the loop input process in which the trainees are presented with input that they can immediately use in their own primary classroom contexts. Nevertheless, the language level of teachers in Slovenia should be higher than an $\mathrm{A}_{2}$ or $\mathrm{B}_{1}$ level; the Slovene teacher training programmes described below aim to achieve a $\mathrm{C} 1$ level.

\section{France}

Dolitsky (2006) introduced suggestions for facilitating practice teaching for pre-service English language teachers. The author illustrates university, cooperating master teachers, and peer-student-teacher support and observe practice teachers as they plan and then take charge of an English class for the first time. The field experience is a reality check after the preceding theoretical training. Although the follow-up conference with the practice teachers is based on the immediate lesson, the author emphasizes the importance of readying teachers for their careers. The aim is to prepare teachers who are striving for constant self-improvement. The process used to help student teachers prepare lessons in detail and analyse their own performance in the classroom is presented so that they will learn to bring about their own personal development as in-service teachers. The French model depicts the significance of a well-organized teaching practice scheme that prepares student teachers for their future profession; thus remains a weak point of some of the existing teacher training programmes in Slovenia.

\section{Sri Lanka}

Hayes (2006) reported on a long-term training programme in a country divided by regional and cultural strife, where opposing regions have different languages and where English is perceived by some as the language of colonists and by others as a language of prestige. The aim of the programme was to provide teachers with needed practical training for primary instruction. Hayes (ibid.) described how innovative approaches were employed to provide 
in-service teacher development at the primary level in state schools in Sri Lanka. Improvement in the quality of schooling is addressed through improved teacher competence. He also stated that it is the teachers who actually decide which methodology will be used in their classrooms and who thus determine the success or failure of educational reforms. No matter how well considered new methodologies are, if teachers do not buy into them, such improvements will be left by the wayside. The lesson we could take from the Sri Lankan programme is that teacher autonomy provides success if teachers are well equipped with methodological knowledge beforehand.

\section{Korea}

Park (2006) described major teacher training initiatives in response to the introduction of English in Grade 3. The author presented the logistical and methodological aspects of the programme and then provides information on the programme's effectiveness. The aim of the programme is to help primary teachers develop skills to teach English as part of the primary curriculum. This aim is accomplished by helping teachers understand the curriculum for elementary school English and develop appropriate teaching methods and skills, improving their ability to use English as a medium of instruction, and preparing them to teach basic communicative language skills. The author offered recommendations, based on feedback from trainees, for designing effective English language education programmes for primary school teachers. The programme shows the importance of basing teacher education on the actual needs of teachers of foreign languages to younger learners, i.e. proper methodological knowledge and fluency in communicative skills; this notion is also at the core of the Slovene programmes.

As these studies show, in many countries there are several training pathways open to primary and language teachers, as well as a variety of approaches are acceptable to employers. In some countries, teachers are given specialized, methodological training, while others are focusing on developing teachers' language skills, supported by the government or teacher training institutions. Unfortunately, based on the evidence from abroad, there is no ideal teacher training model for primary foreign language teaching.

To develop well-qualified and well-trained teachers for young language learners, national language policies should address pre-service and in-service teacher training, which should include foreign language proficiency improvement, coursework on materials development and assessment, classroom observations and meeting individual teachers' professional learning needs. This 
requires a collaborative school culture and interaction with policymakers that promotes the teachers' as well as the pupils' learning with "time for teachers to reflect and develop ideas and resources", as Jones and Coffey (2006, p. 179) asserted.

To compare the abovementioned teacher training contexts to the Slovenian one, the following sections focus in detail on different teacher training programmes for early foreign language education offered in Slovenian universities.

\section{Organisation of higher education in Slovenia}

Higher education in Slovenia is provided by public and private universities, faculties, art academies and professional colleges, and is organized in a similar manner as in other European higher education institutions (Eurydice, 2010). It consists of three cycles:

- $\quad$ First-cycle/level professional or academic (180-240 ECTS),

- $\quad$ Second-cycle/level masters studies (60-120 ECTS),

- Third-cycle/level doctoral studies (180 ECTS).

For a better understanding of the organisation of the initial teacher training in Slovenia offered by state universities (University of Ljubljana, University of Maribor, University of Primorska), we provide a short insight into higher education management. The form of initial education is prescribed by the higher education legislation and education regulations regarding requirements for teachers.

Teachers may obtain the required education and training in the study programmes at the three abovementioned universities, specifically at the Faculty of Arts and at the Faculty of Education. They educate and train educators at the pre-primary level, primary level and subject teacher level as well as for other professional specifications (e.g. inclusive education and training of children and youth with special needs). One of the differences between the two abovementioned faculties is the duration of the study programme. The duration of the bachelor study for students at the faculties of arts is three years and two years of master studies. The duration of the bachelor study for students attending faculties of education is four years and one year of upgrading their specialized knowledge (master's). All members of teaching staff in the primary school must hold a master's degree. 


\section{Models of initial teacher training for primary foreign language teaching in Slovenia}

Primary foreign language education in Slovenia was gradually implemented in the late 1980s and early 1990s; parents were interested in providing their children with quality education, after realizing that knowledge of foreign languages had become extremely important for international communication, and accepting economic and global imperatives. Previously, English or German had been taught from the fifth grade of the eight-year primary education onwards (11 years of age) (see also Jazbec, 2012). As of the late 1980s, the teaching of German and English in the lower classes of primary school began, formally from the fourth grade of the nine-year primary education, but informally, the foreign languages were increasingly taught in the first three grades, which was financially supported mainly by local municipalities. As of September 2013, the first foreign language (either English or German) will be introduced into the first grade of primary school in the form of a pilot scheme until 2015/2016, when it will be introduced into all Slovene schools.

Different studies in the previous two decades (Brumen, 200o; Čagran, 1996; Čok, 1993; Orešič, 1994; Pižorn, 2009) showed that the effects of early language learning and teaching were positive and that early foreign language learning has to be based on an effective foreign language methodology, a research-based curriculum and appropriate materials, and on highly motivated, well trained teachers.

Slovenian state universities are currently making considerable efforts to train sufficient numbers of teachers to teach foreign languages at the primary level, which is a necessary prerequisite (or even the most necessary one) for the successful implementation of foreign languages from the first grade onwards. The Faculties of Arts at the University of Ljubljana and the University of Maribor and the Faculties of Education at the Universities of Ljubljana, Maribor and Primorska offer teachertraining study programmes on teaching foreign languages to young learners. However, each institution offers varied study programmes regarding this issue.

Although the trend in the majority of the European countries is that foreign languages at primary level are taught by primary education teachers qualified to teach all (or almost all) subjects in the curriculum (Eurydice, 2008, p. 77), it has become a common practice in Slovenia that both graduates of foreign language majors and specialist teachers can teach languages in primary schools, as well as primary education teachers with an additional pre-service or in-service teacher training that qualifies them to teach a foreign language to young learners up to Grade 6 (age 12). 
The study programmes described below offer a comparative overview of the courses available to students who want to specialize in teaching a foreign language to young learners. The descriptions are divided into two parts due to their similarity of programmes, i.e. the Faculties of Education are described in the first table and the Faculties of Arts are described in the second table.

Table 1: Pre-service teacher training programme for specializing in teaching a foreign language to young learners at the Faculties of Education in Slovenia

\begin{tabular}{|c|c|c|c|c|c|c|}
\hline University & Faculty & Cycle & Year & Curriculum & $\begin{array}{l}\text { Type of } \\
\text { course }\end{array}$ & ECTS \\
\hline \multirow{14}{*}{$\begin{array}{l}\text { University } \\
\text { of Ljubljana }\end{array}$} & \multirow{14}{*}{$\begin{array}{l}\text { Faculty of } \\
\text { Education }\end{array}$} & \multirow{9}{*}{1} & 1 & Foreign Language - English & obligatory & 4 \\
\hline & & & 2 & English I - Language Skills & elective & 4 \\
\hline & & & 3 & $\begin{array}{l}\text { English II - English Pronun- } \\
\text { ciation for Teachers }\end{array}$ & elective & 4 \\
\hline & & & 4 & $\begin{array}{l}\text { English for Educational } \\
\text { Purposes }\end{array}$ & obligatory & 3 \\
\hline & & & 4 & $\begin{array}{l}\text { English III - C1 Level Exam } \\
\text { Practice }\end{array}$ & elective & 4 \\
\hline & & & \multirow{4}{*}{$2-4$} & $\begin{array}{l}\text { Reading, writing, speaking } \\
\text { and listening in English }\end{array}$ & \multirow{4}{*}{$\begin{array}{l}\text { elective at } \\
\text { the faculty } \\
\text { level }\end{array}$} & 4 \\
\hline & & & & Speaking in English & & 4 \\
\hline & & & & $\begin{array}{l}\text { Reading and writing in } \\
\text { education }\end{array}$ & & 4 \\
\hline & & & & $\begin{array}{l}\text { English and computer sci- } \\
\text { ence in education }\end{array}$ & & 4 \\
\hline & & \multirow{4}{*}{2} & \multirow{4}{*}{5} & $\begin{array}{l}\text { Early English Language } \\
\text { Teaching Methodology I }\end{array}$ & elective & 6 \\
\hline & & & & \begin{tabular}{|l|} 
Early English Language \\
Teaching Methodology II \\
\end{tabular} & elective & 6 \\
\hline & & & & \begin{tabular}{|l|} 
Research in Teaching English \\
to Young Learners
\end{tabular} & elective & 6 \\
\hline & & & & $\begin{array}{l}\text { Language and Intercultural } \\
\text { Awareness }\end{array}$ & $\begin{array}{l}\text { elective at } \\
\text { the faculty } \\
\text { level }\end{array}$ & 6 \\
\hline & & 3 & & $\begin{array}{l}\text { Doctoral study programme } \\
\text { for Educational Studies, } \\
\text { among other subject fields } \\
\text { also offering advanced scien- } \\
\text { tific research based studies } \\
\text { and activities to teaching } \\
\text { (foreign) languages to young } \\
\text { learners. }\end{array}$ & & 180 \\
\hline
\end{tabular}




\begin{tabular}{|c|c|c|c|c|c|c|}
\hline \multirow{6}{*}{$\begin{array}{l}\text { University } \\
\text { of Maribor }\end{array}$} & \multirow{6}{*}{$\begin{array}{l}\text { Faculty of } \\
\text { Education }\end{array}$} & \multirow{4}{*}{1} & 1 & $\begin{array}{l}\text { English or German for Pri- } \\
\text { mary School Teachers }\end{array}$ & obligatory & 4 \\
\hline & & & \multirow{3}{*}{$2-4$} & $\begin{array}{l}\text { The Narrative Approach and } \\
\text { Games in Foreign Language } \\
\text { Learning and Teaching at } \\
\text { Primary Level }\end{array}$ & elective & 4 \\
\hline & & & & $\begin{array}{l}\text { Foreign Language Learning } \\
\text { and Teaching at the Primary } \\
\text { Level }\end{array}$ & elective & 4 \\
\hline & & & & $\begin{array}{l}\text { Teaching English at Pre- } \\
\text { school Level }\end{array}$ & elective & \\
\hline & & 2 & 5 & no courses & & \\
\hline & & 3 & & $\begin{array}{l}\text { Doctoral study programme } \\
\text { for Education Sciences, } \\
\text { among other subject fields } \\
\text { also offering advanced scien- } \\
\text { tific research based studies } \\
\text { and activities to teaching } \\
\text { (foreign) languages to young } \\
\text { learners. }\end{array}$ & & 180 \\
\hline & & & 1 & $\begin{array}{l}\text { Foreign Language - English } \\
\text { or Italian }\end{array}$ & obligatory & 6 \\
\hline & & & & Early Teaching of Italian & elective & 6 \\
\hline & & & & $\begin{array}{l}\text { Italian Phonetics and Phonol- } \\
\text { ogy }\end{array}$ & elective & 3 \\
\hline & & 1 & & English Language Skills & elective & 6 \\
\hline & & & $2-4$ & $\begin{array}{l}\text { Speaking and Writing in } \\
\text { English }\end{array}$ & elective & 6 \\
\hline & & & & $\begin{array}{l}\text { Social Dimensions of the } \\
\text { English Language }\end{array}$ & elective & 3 \\
\hline & & & & $\begin{array}{l}\text { Children's Literature in } \\
\text { English }\end{array}$ & elective & 6 \\
\hline $\begin{array}{l}\text { University } \\
\text { of } \\
\text { Primorska* }\end{array}$ & $\begin{array}{l}\text { Faculty of } \\
\text { Education }\end{array}$ & 2 & 5 & $\begin{array}{l}\text { A new module for teaching } \\
\text { English to young learners } \\
\text { is still in the accreditation } \\
\text { process, consisting of three } \\
\text { courses (focused on various } \\
\text { aspects of teaching English } \\
\text { to young learners and on } \\
\text { teaching practice). The } \\
\text { module will enable students } \\
\text { to gain the qualification for } \\
\text { teaching English in the first } \\
\text { and second three-year cycle } \\
\text { of primary school. }\end{array}$ & & \\
\hline & & & & $\begin{array}{l}\text { Early English Language Teach- } \\
\text { ing Methodology (as part of } \\
\text { the doctoral study programme } \\
\text { for Education Sciences) }\end{array}$ & elective & 12 \\
\hline & & 3 & & $\begin{array}{l}\text { Content and Language } \\
\text { Integrated Learning of Foreign } \\
\text { Languages - CLIL (as part of } \\
\text { the doctoral study programme } \\
\text { for Education Sciences) }\end{array}$ & elective & 12 \\
\hline
\end{tabular}

* The Faculty of Education, University of Primorska is in a bilingual area of Slovenia, bordering with Italy. 
The table shows that all the faculties of education offer an obligatory course in foreign languages in Year 1, and that it is offered to all the students studying to become primary education teachers. The University of Ljubljana and Primorska offer (obligatory) elective courses to students who want to specialize in teaching English to children on the masters (MA) level. In addition to their primary education studies, students can choose to specialize in teaching English to young learners by attending elective courses, focusing on developing their linguistic and methodological skills. Furthermore, the table shows that at the bachelor's (BA) level, the focus is on developing students' language skills, and the MA level gives more emphasis on the methodological skills. On completion of this study programme, teachers gain qualifications for teaching English besides other subjects in the first and second cycle of the primary school.

The Faculty of Education at the University of Maribor does not offer an MA in teaching foreign languages to children but offers the abovementioned elective courses to all students studying to become primary education teachers. Thus, on completion of this study programme, teachers do not gain any qualifications for teaching English at the primary level. However, if they want to teach foreign languages in primary schools they have to finish the in-service teacher education programme described in the next chapter.

We present a similar comparative overview for the Faculties of Arts in Slovenia.

As evident from the table, there are no courses for early foreign language teacher training (EFLTT) in the first cycle at the Faculties of Arts. In the second cycle, the Teacher Education study programme covers general psychologicalpedagogical-methodological issues relevant to teaching (for example in courses such as Psychology for Teachers, or Foreign Language Teaching Methodology). However, these courses generally focus more on teaching older learners and do not put special emphasis on teaching younger learners. At the Department for German Studies at the University of Maribor, students can (in addition to their general Foreign Language Teaching Methodology course) choose between two elective modules, either the module for teaching young learners, or the module for teaching adults, and gain competences for a specific teacher profile. They become qualified teachers of German; if they choose the Young Learners' module they are additionally qualified for teaching younger learners and the name of the module is written on the certificate of graduation. 
Table 2: Pre-service teacher training programme for specializing in teaching a foreign language to young learners at the Faculties of Arts in Slovenia

\begin{tabular}{|c|c|c|c|c|c|c|}
\hline University & Department & Cycle & Year & Curriculum & $\begin{array}{l}\text { Type of } \\
\text { course }\end{array}$ & ECTS \\
\hline \multirow{8}{*}{$\begin{array}{l}\text { University } \\
\text { of Ljubljana, } \\
\text { Faculty of } \\
\text { Arts }\end{array}$} & \multirow[b]{4}{*}{$\begin{array}{l}\text { Department } \\
\text { for English } \\
\text { and American } \\
\text { Studies }\end{array}$} & 1 & $1-3$ & No EFLTT courses & & \\
\hline & & \multirow{2}{*}{2} & \multirow[b]{2}{*}{$4-5$} & Children's Literature & elective & 3 \\
\hline & & & & $\begin{array}{l}\text { Teaching English to Differ- } \\
\text { ent Age Groups }\end{array}$ & elective & 3 \\
\hline & & 3 & & $\begin{array}{l}\text { Doctoral study programme } \\
\text { of Foreign Language Teach- } \\
\text { ing Methodology, among } \\
\text { other subject fields also } \\
\text { offering a possibility of } \\
\text { advanced scientific research } \\
\text { based studies and activities } \\
\text { to teaching foreign lan- } \\
\text { guages to young learners. }\end{array}$ & & 180 \\
\hline & \multirow[b]{4}{*}{$\begin{array}{l}\text { Department } \\
\text { for German } \\
\text { Studies }\end{array}$} & 1 & $1-3$ & No EFLTT courses & & \\
\hline & & \multirow{2}{*}{2} & \multirow{2}{*}{$4-5$} & $\begin{array}{l}\text { Children and Youth Lit- } \\
\text { erature }\end{array}$ & elective & 3 \\
\hline & & & & $\begin{array}{l}\text { Early Learning and Teach- } \\
\text { ing of German }\end{array}$ & elective & 3 \\
\hline & & 3 & & $\begin{array}{l}\text { Doctoral study programme } \\
\text { of Foreign Language Teach- } \\
\text { ing Methodology, among } \\
\text { other subject fields also } \\
\text { offering a possibility of } \\
\text { advanced scientific research } \\
\text { based studies and activities } \\
\text { to teaching foreign lan- } \\
\text { guages to young learners. }\end{array}$ & & 180 \\
\hline \multirow{6}{*}{$\begin{array}{l}\text { University } \\
\text { of Maribor, } \\
\text { Faculty of } \\
\text { Arts }\end{array}$} & \multirow[b]{3}{*}{$\begin{array}{l}\text { Department } \\
\text { for English } \\
\text { and American } \\
\text { Studies }\end{array}$} & 1 & $1-3$ & No EFLTT courses & & \\
\hline & & 2 & $4-5$ & $\begin{array}{l}\text { Teaching English at the } \\
\text { Primary Level }\end{array}$ & elective & 3 \\
\hline & & 3 & & $\begin{array}{l}\text { Doctoral study programme } \\
\text { for Specialist Studies, with } \\
\text { the emphasis on advanced } \\
\text { research based studies to } \\
\text { teaching foreign languages } \\
\text { to young learners }\end{array}$ & & 180 \\
\hline & \multirow[b]{3}{*}{$\begin{array}{l}\text { Department } \\
\text { for German } \\
\text { Studies }\end{array}$} & 1 & $1-3$ & No EFLTT courses & & \\
\hline & & 2 & $4-5$ & $\begin{array}{l}\text { Early Foreign Language } \\
\text { Learning - German }\end{array}$ & elective & 9 \\
\hline & & 3 & & $\begin{array}{l}\text { Doctoral study programme } \\
\text { for Specialist Studies, } \\
\text { among other subject fields } \\
\text { also offering advanced } \\
\text { scientific research based } \\
\text { studies and activities to } \\
\text { teaching foreign languages } \\
\text { to young learners. }\end{array}$ & & 180 \\
\hline
\end{tabular}


On completion of the other study programmes at the faculties of arts, teachers gain qualifications for teaching languages in the second and the third three-year cycle of the primary level and at all higher levels. However, teachers still need to complete some additional teacher training courses to teach in the first cycle of the primary school.

The vertical analysis of the presented study programmes shows that teacher training education in Slovenia offers different paths to becoming a teacher of foreign languages at the primary level. Most of the faculties focus on developing students' foreign language skills in the first cycle and only start developing their methodological skills in the second cycle. Faculties of education address the issue of early foreign language training more specifically, and their graduates can teach in the first and second cycles of primary school only, whereas the graduates from the faculties of arts can teach across all levels.

The tables above show a great variety of teacher training education in Slovenia despite having the same education system in all regions. Therefore, we recommend to language policy and national study programme designers that a general, national study programme policy should be developed, offering foreign language proficiency and adequate methodological preparation for teaching foreign languages at primary level.

\section{In-service teacher education}

In 1998 at the Faculties of Education in Ljubljana and Primorska (at that time still a part of the University of Ljubljana) and in 2000 in Maribor, a new two-year in-service teacher training programme for primary school teachers who had already finished the Primary Education study programme was launched. In Ljubljana, it was offered for the English language, in Maribor for the English and the German languages and in Primorska for the Italian language. In Ljubljana, it was carried out until 2002 for both, pre-service and in-service teachers (Dagarin \& Andraka, 2007, p. 10). In the year 2002, the last generation of full-time students was enrolled as a result of a new way of financing university programmes. From that time onward until 2009, the programme was carried out only in its in-service form.

Dagarin and Andraka (ibid.) reported that upon completion of the programme, teachers were awarded a certificate that qualified them to teach a foreign language to children up to Grade 6 (age 12). Teachers could teach English or Italian or German, depending on which language they had studied during their BA programme (before the Bologna reform, when the duration of BA study was four years). 
The programme comprised three main areas (750 contact hours):

- The language module (525 hours) focused on developing primary school teachers' linguistic, communication and pronunciation competence included Practical English Classes, Grammar for Teachers and Phonetics and Phonology.

- The ELT methodology module (135 hours) focused on methodology for teaching foreign languages to children and on non-verbal means of communication (how to teach a foreign language through art, music, movement and puppetry).

- The literature module (90 hours) introduced general and children's literature in a foreign language (focused on the theoretical, historical and methodological aspects of children's literature.).

Table 3: Number of groups and participants at the in-service programme for primary school teachers from 1998 to 2009 at the Universities of Ljubljana and Maribor

\begin{tabular}{|l|c|c|c|c|c|c|}
\hline \multirow{2}{*}{ Year } & \multicolumn{3}{|c|}{ Number of groups } & \multicolumn{3}{c|}{ Number of participants } \\
\cline { 2 - 7 } & Ljubljana & \multicolumn{2}{|c|}{ Maribor } & Ljubljana & \multicolumn{2}{c|}{ Maribor } \\
\cline { 2 - 7 } & EN* & EN & GERM** & EN & EN & GERM \\
\hline $1998-2000$ & 2 & & & $22+25$ & & \\
\hline $1998-2001$ & 1 & & & 26 & & \\
\hline $2000-2004$ & 1 & 2 & 1 & 18 & $40+32$ & 22 \\
\hline $2001-2005$ & 1 & & & 16 & $14+39$ & 16 \\
\hline $2002-2006$ & 1 & 2 & 1 & 14 & & \\
\hline $2000-2002$ & 1 & & & 17 & & \\
\hline $2002-2004$ & 1 & & & 20 & & \\
\hline $2003-2005$ & 1 & & & 31 & & \\
\hline $2004-2006$ & 1 & 1 & & 32 & 16 & \\
\hline $2005-2007$ & 1 & & & 31 & & \\
\hline $2006-2008$ & 1 & 1 & & 26 & 26 & \\
\hline $2007-2009$ & 1 & & & 24 & & \\
\hline $2008-2010$ & 1 & & & 31 & & \\
\hline Total: & 14 & 6 & 2 & 302 & 167 & 38 \\
\hline
\end{tabular}

* Groups of participants training to teach English to young learners

** Groups of participants training to teach German to young learners

(Source: Admission managers at the Faculties of Education, Universities of Ljubljana and Maribor, 2. 7. 2012)

By the end of June 2012, 153 in Ljubljana and 77 participants in Maribor (75 for the English language and only two for the German language) had 
successfully finished the programme and been awarded the certificates that allow them to teach English or German in the first and second three-year cycles of primary school. Approximately half of the participants who attended the programme from 1998 to 2009 have not finished all the obligations yet and have thus not received the certificates. There are various reasons for this. Firstly, the participants were practising teachers, often with family obligations besides their teaching and study obligations. They attended the classes in the afternoons and on Saturdays and there was a great deal of self-study involved. The research, conducted in 2003, showed that the participants found the programme very demanding and the courses too tightly packed (Dagarin \& Andraka, 2007, p. 16; Pižorn \& Dagarin, 2006). The Faculty of Education at the University of Ljubljana has assigned a deadline for the participants who have not finished their studies yet: they have to finish their obligations by 31 August 2016 if they want to teach English to young learners.

Table 3 also shows that only two groups enrolled for the German language. English is the lingua franca and is taught as the first foreign language throughout the country from pre-school onwards. German has, however, retained its strong position as an important language and is the most common second foreign language in primary schools.

From 2010 onwards, all the in-service programmes at the universities had to be reformed in line with the Bologna Process and thus in October 2011 the Faculty of Education at the University of Ljubljana offered a reformed inservice study programme for pre-school teachers, primary teachers and special education and rehabilitation teachers. Approximately 50 teachers have now finished the first year of this programme. The second programme, an in-service programme for specialist teachers (English), is still in the process of accreditation. Both programmes take 6o ECTS.

The study programme for pre-school teachers, primary teachers and special education and rehabilitation teachers consists of two main modules:

- Developing students' English language skills (subjects Language Skills I and II, English phonetics and phonology and English Grammar for teachers (36 ECTS).

- Developing students' methodology skills in teaching English to young learners (obligatory subject in English language teaching methodology for young learners (12 ECTS) and two elective subjects (12 ECTS). Students have a wide variety here and can choose among six different subjects, mainly focusing on didactic issues, e.g. CLIL, children's literature, drama, storytelling and rhymes, creating and evaluating materials, integrating art, movement, puppets and music into teaching English to children. 
The study programme for specialist teachers (English), which is still in the process of accreditation, consists of obligatory modules focusing on early childhood psychology, pre-school education, the methodology in teaching English to young children (pre-school and first cycle of primary school), CLIL, teaching a foreign language to special-needs students and one elective module (in which the emphasis is on additional methodological skills, e.g. storytelling, using rhymes, games in teaching English to children, integration of other subjects into English and teaching other subjects in English, assessing young learners in English etc.).

On completion of this study programme, specialist teachers can teach English in the first cycle of primary school.

Table 4: In-service teacher training programmes at the University of Ljubljana

\begin{tabular}{|c|c|c|c|}
\hline $\begin{array}{l}\text { Study } \\
\text { programmes }\end{array}$ & Participants & Curriculum & 60 ECTS \\
\hline \multirow{5}{*}{$\begin{array}{l}\text { Study } \\
\text { programme } 1\end{array}$} & \multirow{5}{*}{$\begin{array}{l}\text { Pre-primary, primary } \\
\text { and special education } \\
\text { and rehabilitation } \\
\text { teachers }\end{array}$} & Language Skills I and II & 18 \\
\hline & & English Phonetics and Phonology & 6 \\
\hline & & English Grammar for Teachers & 12 \\
\hline & & $\begin{array}{l}\text { Methodology of Teaching Foreign Lan- } \\
\text { guages to Young Learners }\end{array}$ & 12 \\
\hline & & Two elective subjects & 12 \\
\hline \multirow{8}{*}{$\begin{array}{l}\text { Study } \\
\text { programme } 2\end{array}$} & \multirow{8}{*}{ Specialist teachers } & Early Childhood Psychology & 6 \\
\hline & & Pre-school Education & 6 \\
\hline & & $\begin{array}{l}\text { Methodology in Teaching English in the } \\
\text { Pre-school Period }\end{array}$ & 7 \\
\hline & & $\begin{array}{l}\text { Methodology in Teaching English in the } \\
\text { First Cycle of Primary School }\end{array}$ & 7 \\
\hline & & CLIL & 6 \\
\hline & & $\begin{array}{l}\text { Teaching a Foreign Language to Special } \\
\text { Needs Students }\end{array}$ & 6 \\
\hline & & Teaching Practice & 10 \\
\hline & & Two elective subjects & 12 \\
\hline
\end{tabular}

The Faculty of Arts and the Faculty of Education of the University of Maribor have developed a new study programme, which has not been accredited yet. It is a joint, co-operative one-year study programme between two faculties, in which professors from different departments (Department of German Studies and Department of English and American Studies, Department of Primary Teacher Education) contribute in the same programme. It is the first time that some active professors have organized and planned the study programme together. It is a new in-service interdisciplinary programme in which psychological-pedagogical and didactic aspects as well as foreign language and subject specific aspects from subject-specific methodological areas (mathematics, environmental science, art, 
music and sport) have been combined, bringing together content- and languageintegrated learning (CLIL) at the primary level. The study programme is offered to pre-school teachers, primary teachers, special education and rehabilitation teachers, who detail their language proficiency on $\mathrm{B}_{2}$ level, and to specialist teachers (English and German teachers) special education and foreign language competences for teaching languages at the primary level. It involves 6o ECTS.

The study programme introduces the following modules:

- $\quad$ Module 1: Didactic principles for foreign language teaching at the primary level (30 ECTS), attended by all participants;

- $\quad$ Module 2: Foreign language proficiency for pre-primary, primary and special education and rehabilitation teachers, or a pedagogic-didactic module for specialist teachers (English and German teachers), 24 ECTS; - $\quad$ Elective module: according to the subject field, a participant chooses two elective courses (6 ECTS) from different study programmes (Department of Pre-primary and Primary Teacher Education / Department of English and American Studies / Department of German Studies).

Table 5: In-service teacher training programme at the University of Maribor

\begin{tabular}{|c|c|c|c|}
\hline Module & Participants & Curriculum & 60 ECTS \\
\hline \multirow{3}{*}{ Module 1} & \multirow{3}{*}{ All } & $\begin{array}{l}\text { Methodology of Teaching Foreign } \\
\text { Languages to Young Learners }\end{array}$ & 12 \\
\hline & & CLIL & 6 \\
\hline & & Teacher Training & 12 \\
\hline \multirow{5}{*}{ Module 2} & \multirow{2}{*}{$\begin{array}{l}\text { Pre-primary, primary and } \\
\text { special education and } \\
\text { rehabilitation teachers }\end{array}$} & $\begin{array}{l}\text { Introduction to English (or German) } \\
\text { Language }\end{array}$ & 3 \\
\hline & & $\begin{array}{l}\text { Language Competences } 1 \text { and } 2 \text { (Eng- } \\
\text { lish, German) }\end{array}$ & 21 \\
\hline & \multirow{3}{*}{ Specialist teachers } & $\begin{array}{l}\text { Psychology of Teaching Foreign Lan- } \\
\text { guages in Childhood }\end{array}$ & 6 \\
\hline & & $\begin{array}{l}\text { Methodology of Teaching Mathematics } \\
\text { and Methodology of Teaching Environ- } \\
\text { mental Education }\end{array}$ & 9 \\
\hline & & $\begin{array}{l}\text { Aesthetics and Movement - Basic } \\
\text { Methodology of Teaching Art, Music } \\
\text { and Sports }\end{array}$ & 9 \\
\hline \multirow{2}{*}{$\begin{array}{l}\text { Elective } \\
\text { module }\end{array}$} & $\begin{array}{l}\text { Pre-primary, primary and } \\
\text { special education and } \\
\text { rehabilitation teachers }\end{array}$ & $\begin{array}{l}2 \text { elective courses from the language } \\
\text { department }\end{array}$ & 6 \\
\hline & Specialist teachers & $\begin{array}{l}2 \text { elective courses from the (pre)- } \\
\text { primary department }\end{array}$ & 6 \\
\hline
\end{tabular}

The abovementioned study programme is a unique, interdisciplinary programme in Slovenia, combining different teachers' profiles. 
On completion of both study programmes in Ljubljana and Maribor, pre-school teachers gain qualifications to teach English (and German in Maribor) at the pre-school level and in the first grade of primary school, primary school teachers gain qualifications to teach English (or German) in the first and second cycle of primary school, while special education and rehabilitation teachers gain qualifications to teach English in the third cycle of primary schools which follow the adapted programme.

A teacher-training course for teaching English to young learners, developed at the Faculty of Education, University of Primorska, is in the process of accreditation. The course will be carried out in co-operation with the Faculty of Humanities, University of Primorska. It is primarily intended for in-service primary school teachers who will thus gain the qualification to teach English in the first and second cycle of primary school and pre-school teachers who will be able to teach English at pre-school level and in the first grade of primary school. The course is based on two main foci: first, the development of English language competences, i.e. linguistic, pragmatic and sociolinguistic competences which are relevant for teaching English at young-learners level; and second, the methodological principles and practical aspects of teaching English to young learners. ${ }^{4}$

All the abovementioned programmes offer additional qualifications for teaching foreign languages at the (pre)primary level (ages $3 / 4$ to 11/12).

Since the White Paper on Education (Bela Knjiga, 2011, p. 128) and the Official Gazette of the Republic of Slovenia (dated 2nd November 2011, Act 20) state that foreign languages in the first three-year cycle of primary school are to be taught by either primary school teachers or specialist teachers who have finished a teacher training programme for teaching foreign languages to children, both pre-service and in-service programmes are needed to educate enough teachers for implementing foreign languages into the pre-primary and early primary periods. The authors presume that more acts will be accepted in the future regarding the training of teachers.

At the moment, there are not enough teachers with qualifications for teaching foreign languages to children as the programme for specialist teachers has not been executed yet and not many teachers have finished the programme for primary school teachers (see Table 3 ).

The abovementioned programmes are a solution to the lack of qualified teachers, which (as was previously discussed), is not only a problem in Slovenia, but throughout the whole world. Although initial teacher training institutions

4 Unfortunately, due to confidentiality reasons, a more detailed description of the programme at the University of Primorska was not available at the time of writing of the article. 
in Slovenia offer varied study programmes to teaching foreign languages to young learners, a national study programme policy with a regular pre-service national programme should be developed, offering foreign language proficiency and specific methodological features of teaching languages with particular reference to young learners and to the integration of additional languages in other curriculum areas at this level.

\section{Conclusion}

It is true that there are various expectations, necessities, and recommendations for any teacher training programme regarding the teachers, the duration of training, or the objectives of training. The present overview of the training programmes abroad and in Slovenia offers opportunities for reflection and change in some educational contexts. Some introduced studies may not work across different contexts; nevertheless, all of them contain some characteristics that may be relevant for the Slovenian situation.

We believe that in addition to studying other teacher training programmes, educational policy and training staff should first and foremost consider accepting teachers' (individual) requirements, needs and recommendations, analyse them and include them in their programmes. More opportunities to become competent users of foreign language, participation in exchange programmes in foreign-speaking countries, as well as general pedagogical and methodological understanding of how languages are learnt should be offered to teachers. Furthermore, with careful preparation, well-structured lessons, and training teachers in self-assessment and self-improvement, teachers will strengthen their teaching through critical reflection on their performance and will improve the quality of their instruction. We are convinced that offering well-devised teacher training programmes to teachers of foreign languages at the primary level will raise the level of quality of foreign language instruction at this level and will create confident and communicative foreign language users.

\section{References}

Brumen, M. (2011). The Perception of and Motivation for Foreign Language Learning in Pre-School. Early Child Development and Care, 181(6), 717-732.

Brumen, M. (2000). Didaktične značilnosti pouka zgodnjega učenja tujega jezika v SV delu Slovenije. Pedagoška obzorja, 15(3-4), 151-167.

Bela knjiga o vzgoji in izobraževanju v Republiki Sloveniji (2011). Ljubljana: Zavod RS za šolstvo. Calabrese, R., \& Dawes, B. (2008). Early language learning and teacher training: a foreign language 
syllabus for primary school. Studi di Glottodidattica, 1, 32-53.

Chodiah, I. (2008). English in primary school: gem in the mud. Paper presented at the Bangalore conference, The way forward: learning from international experience of TEYL, 3-6 January, 2008. RIESI: Bangalore, India.

Čagran, B. (1996). Evalvacija projekta Tuji jeziki na razredni stopnji. Ljubljana: Zavod Republike Slovenije za šolstvo.

Čok, L. (1993). Usvajanje maternega, drugega in tujega jezika v otroški dobi. In I. Štrukelj (Ed.), Jezik tako in drugače : zbornik (pp. 120-130). Ljubljana: Društvo za uporabno jezikoslovje Slovenije. Dagarin, M., \& Andraka, M. (2007). Evaluation of teacher training programmes for primary teachers of English - A comparative study. In M. Nikolov, J. Mihaljević Djigunović, M. Mattheoudakis, G. Lundberg, \& T. Flanagan (Eds.), Teaching modern languages to young learners: teachers, curricula and materials (pp. 9-21). Strasbourg/Graz: Council of Europe/European Centre for Modern Languages. Dendrinos, B. (2010). Early Language Learning in Europe. European Commission Report. Retrieved on 20.06.2012 from http://rcel.enl.uoa.gr/docsforpeap/EARLY\%2oLANGUAGE\%2oLEARNING\%20 IN\%20EUROPE.pdf

Dolitsky, M. (2006). The French Communicative Connection: Catching Up. In M. L. McCloskey, J.

Orr, \& M. Dolitsky (Eds.), Teaching English as a Foreign Language in Primary School (pp. 177-190).

Virginia: TESOL (Teachers of English to Speakers of Other Languages, Inc.

Edelenbos, P., Johnstone, R., \& Kubanek, A. (2006). The main pedagogical principles underlying the teaching of languages to very young learners. Languages for the children of Europe: Published Research, Good Practice and Main Principles. Final Report of the EAC 89/o4, Lot 1 Study. European Commission, Brussels: Education and Culture, Culture and Communication, Multilingualism Policy. Retrieved on 20.06.2012 from http://ec.europa.eu.education/languages/pdf/doc425_en.pdf Emery, H. (2012). A global study of primary English teachers' qualifications, training and career development. ELT Research Papers 12-08. UK: British Council.

Enever, J. (Ed.). (2011). ELLiE. Early Language Learning in Europe. UK: British Council.

Enever, J., Moon, J., \& Raman, U. (2009). Young Learner English Language Policy and Implementation: International Perspectives. Reading, UK: Garnet Education.

Eurydice (2008). Key data on Teaching Languages at School in Europe. Brussels: Education,

Audiovisual and Culture Executive Agency.

Eurydice (2010). Structures of Education and Training Systems in Europe, Slovenia 2009/1o Edition.

Brussels: Education, Audiovisual and Culture Executive Agency.

Garton, S., Copland, F., \& Burns, A. (2011). Investigating Global Practices in Teaching English to Young Learners. UK: British Council.

Graddol, D. (2006). English Next: Why Global English May Mean the End of 'English as a foreign language'. UK: British Council.

Graddol, D. (2008). How TEYL is changing the world. Paper presented at the Bangalore conference, The way forward: learning from international experience of TEYL, 3-6 January, 2008. Bangalore, India: RIESI. 
Hayes, D. (2006). Developing Teachers in the Developing World of Sri Lanka. In M. L. McCloskey, J. Orr, \& M. Dolitsky (Eds.), Teaching English as a Foreign Language in Primary School (pp. 141-155). Virginia: TESOL (Teachers of English to Speakers of Other Languages), Inc. Hildén, R., \& Kantelinen, R. (2012). Language Education - Foreign Languages. In H. Niemi, A. Toom, \& A. Kallioniemi (Eds.), Miracle of Education. The Principles and Practices of Teaching and Learning in Finnish Schools (pp. 161-176). Rotterdam: Sense Publishers.

Ibrahim, N. A. (1991). In-service training in Malaysia for the New Primary Curriculum (KBSR). In K. M. Lewin, \& J. S. Stuart (Eds.), Educational innovation in developing countries: Case studies of changemakers (pp. 95-126). London: Macmillan. Jazbec, S. (2012). Zur Stellung von Deutsch als Fremdsprache im slowenischen Ausbildungskontext. In H. Breitenfellner \& M. Škofljanec (Eds.), Avstrija, Slovenija: kulturni stiki = kulturelle Begegnungen (pp. 109-124). Maribor: Univerzitetna knjižnica.

Jones, J., \& Coffey, S. (2006). Modern Foreign Languages 5-11: A Guide for Teachers. London: David Fulton Publishers.

Lamb, M. (1996). The consequences of INSET. In T. Hedge, \& N. Whitney (Eds.), Power, Pedagogy and Practice (pp. 139-149). Oxford, England: OUP.

Lipavic Oštir, A. (2010). Organizacija in okoliščine izvajanja zgodnjega učenja tujih jezikov na osnovnih šolah. In A. Lipavic Oštir \& S. Jazbec (Eds.), Pot v večjezičnost - zgodnje učenje tujih jezikov v 1. VIO osnovne šole (pp. 16-30). Ljubljana: Zavod RS za šolstvo.

Lundberg, G. (2007). Developing teachers of young learners: in-service for educational change and improvement. In M. Nikolov, J. Mihaljević Djigunović, M. Mattheoudakis, G. Lundberg, \& T. Flanagan (Eds.), Teaching Modern Languages to Young Learners: Teachers, Curricula and Materials (pp. 21-34). Strasbourg/Graz: Council of Europe/European Centre for Modern Languages.

Moon, J., \& Boullớn, R. L. (1997). Reluctance to reflect: Issues in professional development. In D. Hayes (Ed.), In-service teacher development: International perspectives (pp. 60-73). Hemel Hempstead, England: Prentice Hall.

Noffke, S. E., \& Somekh, B. (Ed.). (2009). The Sage Handbook of Educational Action Research. Los Angeles and London: Sage Publications.

Orešič, H. (1994). Tuji jeziki na razredni stopnji osnovne šole. In L. Čok (Ed.), Učiti drugi/tuji jezik: kje, koga, kako, (Tempus Joint European Project 3767) (pp. 123-129). Ljubljana: Pedagoška fakulteta. Park, S. H. (2006). EFL Teacher Training for South Korean Elementary School Teachers. In M. L. McCloskey, J. Orr, \& M. Dolitsky (Eds.), Teaching English as a Foreign Language in Primary School, (pp. 191-200). Virginia: TESOL (Teachers of English to Speakers of Other Languages), Inc. Pennycuick, D. (1993). School effectiveness in developing countries: A summary of the research evidence. London: Overseas Development Administration.

Pevec Semec, K., \& Pižorn, K. (2010). Predstavitev projekta sporazumevanje v tujih jezikih/uvajanje tujega jezika (UTJ) in jezikovnega/medkulturnega uzaveščanja (JIMU) v prvo vzgojno-izobraževalno obdobje OŠ (1.4. 2008 - 1.4. 2010). In A. Lipavic Oštir, \& S. Jazbec (Eds.), Pot v večjezičnost - zgodnje učenje tujih jezikov v 1. VIO osnovne šole (pp. 6-16). Ljubljana: Zavod RS za šolstvo. 
Pižorn, K., \& Dagarin Fojkar, M. (2006). Študija primera - dvopredmetni univerzitetni študijski program za izobraževanje učiteljev angleščine na zgodnji stopnji in implementacija evropskega jezikovnega profila za izobraževanje učiteljev jezikov. In P. Zgaga (Ed.), Posodobitev pedagoških študijskih programov v mednarodnem kontekstu (pp. 163-179). Ljubljana: Pedagoška fakulteta. Rixon, S. (Ed.). (1999). Young Learners of English: Some Research Perspectives. Harrow: Pearson Education Limited.

Tinker Sachs, G., \& Mahon, T. (2006). Practices in the Teaching and Learning of English in Hong Kong. In M. L. McCloskey, J. Orr, \& M. Dolitsky (Eds.), Teaching English as a Foreign Language in Primary School (pp. 201-222). Virginia: TESOL (Teachers of English to Speakers of Other Languages), Inc.

Uradni list RS (Official Gazette of the RS), No. 87/2011 dated 2.11.2011, p. 11317.

Wang, Q. (2002). Primary school English teaching in China new developments. English Language Teacher Education and Development, 7, 99-108.

Wang, Q. (2007). 'The National Curriculum Changes and their Effects on ELT in the People's Republic of China'. In J. Cummins \& C. Davison (Eds.). The International Handbook of English Language Teaching, Volume 1 (pp. 87-105). Norwell, Massachusetts: Springer Publications. Wang, Q. (2009). Primary English in China: Policy, curriculum and implementation. In M. Nikolov (Ed.), Contextualizing the Age Factor: Issues in Early Foreign Language Learning. Berlin: Mouton de Gruyter.

\section{Biographical note}

Mihaela BRUmen, is an associate professor of early learning of foreign languages at the Faculty of Education, University of Maribor. Her research interests are foreign language teaching and learning at the pre-primary and primary school level.

Mateja Dagarin Fojkar, has a PhD in Teaching English to young learners and works at the Faculty of Education, University of Ljubljana. Her main research areas include teaching foreign languages to young learners and developing communicative and literacy skills in beginner learners of English. 